MH Egészségügyi Központ Védelem Egészségügyi Igazgatóság Pszichológiai és Egészségmagatartási Intézet Egészségfejlesztési Osztály

\title{
A Honvéd Testalkati Program tapasztalatai
}

\author{
Dr. Juhász Zsolt alezredes, PhD, \\ Rázsó Zsófia hadnagy
}

Kulcsszavak: egészség, Honvéd Testalkati Program, életmódváltás, Magyar Honvédség

A Magyar Honvédség vezetése a Zrínyi 2026 Haderőfejlesztési Programban külön figyelmet szentel a katonák egészséges életmódjának kialakítására, fenntartására. A 2015-ben elindított Honvéd Testalkati Program (a továbbiakban: Program vagy HTP) fö célja a testsúlyfelesleggel rendelkezők 12 hónapos életmódváltásának támogatása. A HTP az amerikai hadseregben müködő „Army Body Composition Program” (AR 600-9, 2013) alapján került implementálásra a magyar haderőben, mely szaktevékenység a munkahelyi egészségfejlesztés keretében valósul meg. A 12 hónapos programot befejezők esetében igen jó eredmények figyelhetök meg az életmódváltás tekintetében. Az egy év elteltével, a BMI érték csökkenése átlagosan $5 \mathrm{~kg} / \mathrm{m}^{2}, a z$ átlagos testtömeg értékváltozás $-16 \mathrm{~kg}$, a testzsír százalék átlagos csökkenése 6\%. A zsigeri zsír egy év elteltével átlagosan 2 egységgel csökkent. A motivációs struktúrát tekintve a leginkább motiváló tényezők az egészség megőrzése (betegségek elkerülése), a testsúlykontroll, revitalizáció, illetve az erö-állóképesség fejlesztése volt. Az eredmények alátámasztják, hogy az egészségügyi haderővédelem (force health protection) részeként indított életmódváltás támogatás hozzájárul az állomány harckészültségének és hosszútávú munkavégző képességének megőrzéséhez. 


\section{Bevezetés}

Az elhízást az Egészségügyi Világszervezet (WHO) 1997-ben világjárványnyá nyilvánította [1]. Az egészségügyi kockázatok mellett számos, az életminőség romlásához vezető egyéb tényező is szerepet játszhat az egyén életében [2]. Az elhízás hátterében az egészségügyi problémák mellett az egészségtelen táplálkozás és a fizikai inaktivitás áll. A Magyar Honvédség, mint az ország egyik legnagyobb munkáltatója kiemelten kezeli a személyi állomány egészségvédelmét, egészségének és hadrafoghatóságának hosszútávon történő fenntartását a prevenció mindhárom szintjén (primer, szekunder, tercier) keresztül [3]. Az egészségtudatos életmód - amely hozzájárul a katonák lelki és fizikális jólléti állapotának eléréséhez és ezzel hadrafoghatóságuk növeléséhez - az életmódváltást megcélzó intervenció során alakítható ki [2]. Ennek elérése érdekében a Magyar Honvédség vezetése a Zrínyi 2026 Haderőfejlesztési Programban külön figyelmet szentel a katonák egészséges életmódjának kialakítására, fenntartására. A 2015 óta működő Honvéd Testalkati Program (a továbbiakban: HTP) népszerűsítése és támogatása, továbbra is kiemelt feladatot jelent. A HTP az amerikai hadseregben használt „Army Body Composition Program" (AR 600-9, 2013) alapján került kidolgozásra és implementálásra a magyar haderőben, melynek eredményeképpen ez a szaktevékenység a munkahelyi egészségfejlesztés keretében valósul meg [4]. A Honvéd Testalkati Programot a 2015-ben hatályba lépett 10/2015. (VII. 30.) HM rendelet szabályozza, amely a katonai szolgálatra való egészségi, pszichikai és fizikai alkalmasságról, valamint a felülvizsgálati eljárásról szól
[5]. A cikkben bemutatjuk a résztvevő személyi állomány testösszetétel változásain keresztül a HTP hatékonyságát és eredményességét. A mérési eredmények alapján igazoljuk, hogy azon személyek, akik a programban meghatározottaknak megfelelően jártak el és változtattak életmódjukon, testsúlycsökkenést, illetve kedvező irányú testösszetétel változást értek el, valamint növekedett funkcionális teljesítő képességük is. Eredményeik alátámasztják, hogy a katonai élőerő védelem (Force Health Protection) szempontjából a HTP, mint preventív eszköz továbbra is segítséget nyújthat az állomány bevethetőségének és hosszútávú munkavégző képességének megőrzésében.

\section{Minta, módszer, mérőeszköz}

A mintában ( $\mathrm{N}=390)$ a nők (56\%) felülreprezentáltak. Öket vélhetően érzékenyebben érinti a túlsúly vagy az elhízás, valamint megfelelés orientáltabbak, mint a férfiak. Az átlag életkor 42,81 $\pm 8,77$ év. $\mathrm{Az}$ iskolai végzettséget tekintve $-\mathrm{a}$ többség felsőfokú végzettségü. A program résztvevői az ország különböző fegyveres szervezeteinek (pl.: Honvédség, Rendőrség stb.) személyi állományának tagjai. A testösszetétel (BMI) alapján a legtöbben (203 fö) elhízottak, 109-en túlsúlyosak. A zsírmegoszlás tekintetében a férfiak esetében a viszcerális (zsigeri) zsír, míg a nőknél a bőr alatti zsír dominanciája volt jellemző.

A HTP 12 hónapot ölel fel, 3 havonta történnek a kontroll vizsgálatok. Az első megjelenés alkalmával a résztvevők testösszetétele felmérésre, az általuk korábban megküldött kérdőíveik pedig kiértékelésre kerülnek. Ez alapján a mérések két részre bonthatók. A szubjektív méréseket egy önkitöltős kérdőív segítségé- 
vel végezzük, amely a szociodemográfiai adatok, az önminősített egészségi állapot, eddig előfordult betegségek, mütétek, gyógyszerszedés, (sport)motiváció, a program iránti adherencia témakörökből áll. A fizikai aktivitás gyakoriság felmérésére a Global Physical Activity Questionnaire (GPAQ) tesztet alkalmazzuk [6].

A mozgás és táplálkozás területéhez kapcsolódó viselkedés-változás szándékának felmérése Prochaska és DiClement (1982) transzteoretikus modellje (TTM) segítségével történik [7].

A modell alapján hat fázist különböztetünk meg. Az első a „fontolgatás előtti fázis", ebben a fázisban az egyének nem szándékoznak a belátható jövőben (az elkövetkező 6 hónapon belül) életmódjukon változtatni. A második a „fontolgatás fázisa”, itt az egyének nem törekednek az aktív életmódváltásra, azonban komolyan fontolgatják annak elkezdését az elkövetkező 6 hónapon belül. Ezt követi az „elökészület fázisa”, amelyben az egyéneknek szándékukban áll az egészségtudatos életmód elkezdése az elkövetkező 6 hónapban. A negyedik a „cselekvés fázisa”, az egyének itt már egyértelmü, konkrét életmódbeli változtatásokkal, aktívan törekednek az életmódjuk megváltoztatására. Az ötödik a „fenntartás fázisa”, amelyben az egyének az életmódváltásukat már legalább 6 hónapja sikeresen tartják. Az utolsó a „befejezés fázisa”, ebben a fázisban az egyének már nem esnek kísértésbe és az énhatékonyságuk 100\%os, viszont egy életmódváltó program esetében erről a fázisról nem beszélhetünk, mivel az adott egyénnek egy egész életen át figyelnie kell a táplálkozására és a rendszeres testmozgására, sportmozgására [8]. Az étkezési magatartás felmérésére a Three - Factor - Eating
- Questionnaire (TFEQ-2) tesztet alkalmaztuk, illetve rákérdeztünk korábbi testsúlycsökkentési programok tapasztalataira, továbbá a túlsúly kezdetére [9]. A stressz szint mérésére a mentális állóképesség kvóciens (MÁQ) meghatározására alkalmas kérdéssort [10], illetve az észlelt stressz mérésére (Perceived Stress Scale - PSS-10) szolgáló kérdöívet [11] alkalmaztuk, valamint a pszichológiai immunkompetencia (PIK) mérésére alkalmas kérdőívet használtuk [12]. A motivációs faktorok vizsgálatához EMI-2, 51 itemből álló motivációs kérdőívet alkalmaztuk. A kérdőív 14 skálát (egészség, betegségek elkerülése, revitalizáció, testsúly kontroll, erő és állóképesség, stressz kezelés, sport élvezet, kihívás, rugalmasság, megjelenés, egészségügyi nyomás, tartozni valahová, társadalmi elismerés, verseny) különböztet meg [13].

\section{Eredmények}

\section{Transzteoretikus modell}

A vizsgálatban résztvevőknek arra a kérdésre kellett válaszolniuk, hogy „Hogy látják, hol tartanak a rendszeresebbnek vélt fizikai aktivitásra, illetve az egészségesebbnek vélt táplálkozásra történő áttérés területén?” A HTP résztvevőinek eredményei alapján elmondható, hogy nagy százalékuk a testmozgás esetében $(35,9 \%)$, a táplálkozás esetében $(44,4 \%)$ még a fontolgatás fázisában tart, ők még nem állnak készen egy sikeres életmód változtató program elkezdéséhez (1. ábra). Többek között ez is az egyik oka lehet a nagyszámú lemorzsolódásnak.

Az alapvető TTM modell szerint, minél elörébb tart valaki a fázisokban, annál nagyobb az esélye, hogy tovább marad a programban, illetve sikeresen be is fejezi azt. A jelenlegi minta esetében 


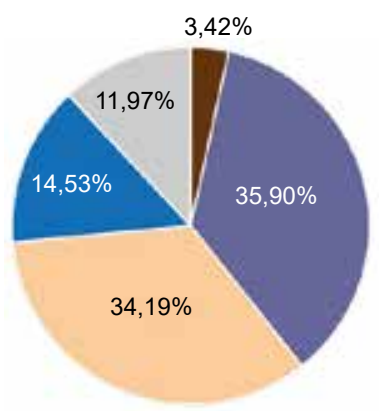

A viselkedésváltozás szakaszok szerinti megoszlása a fizikai aktivitás vonatkozásában.

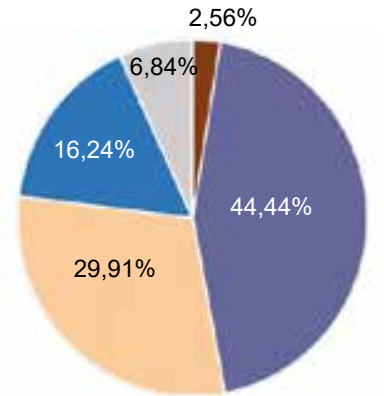

A viselkedésváltozás szakaszok szerinti megoszlása a táplálkozás vonatkozásában.

1. ábra. Eredmények a viselkedés változás transzteoretikus modellje alapján

ez csak részben érvényesül. Itt nagyobb lemorzsolódás figyelhető meg az "elökészület”, „cselekvés”, „fenntartás” fázisában is, ezért feltételezhető, hogy nem „csak” az egyéni elkötelezödés hiánya okozhatja a nagyszámú lemorzsolódást, hanem más, külső tényező is szerepet játszhat benne. Ezek lehetnek pl. a kíváncsiság, szolgálati elfoglaltság, határmenti feladatok, missziók stb.

\section{Sport motiváció}

A sport motiváció felmérésére a vizsgálatban résztvevőknek egy 0-tól 5-ig terjedő skálán kellett válaszolniuk arra a kérdésre, hogy „Személy szerint miért sportolnak?”. Minél magasabb pontszámot adtak egy bizonyos itemre, az annál fontosabb volt számukra a sportolás tekintetében. Az átlag pontszámokat tekintve az első három helyen álló motivációs faktorok mindegyike 3,5 pontnál nagyobb értéket kapott a résztvevők válaszai alapján.

Ezek a következők voltak: „egészség”, „betegségek elkerülése” és a „revitalizáció" (2. ábra).

\begin{tabular}{|l|c|c|l|}
\hline név & $\begin{array}{c}\text { átlag } \\
\text { pont- } \\
\text { szám }\end{array}$ & $\begin{array}{c}\text { sor- } \\
\text { szám }\end{array}$ & $\begin{array}{l}\text { szignifikancia } \\
p<0,05\end{array}$ \\
\hline egészség & $\mathbf{4 , 3 7}$ & $\mathbf{1}$ & \\
\hline $\begin{array}{l}\text { betegségek } \\
\text { elkerülése }\end{array}$ & $\mathbf{4 , 0 1}$ & $\mathbf{2}$ & $\mathrm{p}=0,00003739$ \\
\hline revitalizáció & $\mathbf{3 , 9}$ & $\mathbf{2}$ & $\mathrm{p}=0,27$ \\
\hline testsúly kontroll & $\mathbf{3 , 6 5}$ & $\mathbf{3}$ & $\mathrm{p}=0,0129$ \\
\hline $\begin{array}{l}\text { erő és } \\
\text { állóképesség }\end{array}$ & $\mathbf{3 , 5 7}$ & $\mathbf{3}$ & $\mathrm{p}=0,3979$ \\
\hline stressz kezelés & 3,37 & $\mathbf{4}$ & $\mathrm{p}=0,04431$ \\
\hline sport élvezet & 3,34 & $\mathbf{4}$ & $\mathrm{p}=0,7374$ \\
\hline kihívás & 3,15 & 4 & $\mathrm{p}=0,08178$ \\
\hline rugalmasság & 3,1 & 4 & $\mathrm{p}=0,6553$ \\
\hline megjelenés & 2,66 & 5 & $\mathrm{p}=0,0003413$ \\
\hline $\begin{array}{l}\text { egészségügyi } \\
\text { nyomás }\end{array}$ & 2,06 & 6 & $\mathrm{p}=0,00000342$ \\
\hline tartozni valahová & 1,99 & 6 & $\mathrm{p}=0,5612$ \\
\hline $\begin{array}{l}\text { társadalmi } \\
\text { elismerés }\end{array}$ & 1,53 & 7 & $\mathrm{p}=0,00002426$ \\
\hline verseny & 1,42 & 7 & $\mathrm{p}=0,2504$ \\
\hline
\end{tabular}

2. ábra. A motivációs faktorok sorrendje a HTP résztvevők válaszai alapján

\section{Hatékonyság becslési vizsgálatok}

A Honvéd Testalkati Program hatékonyság becslésének vizsgálati eredményei alapján az átlagértékeket tekintve 95\%-os 


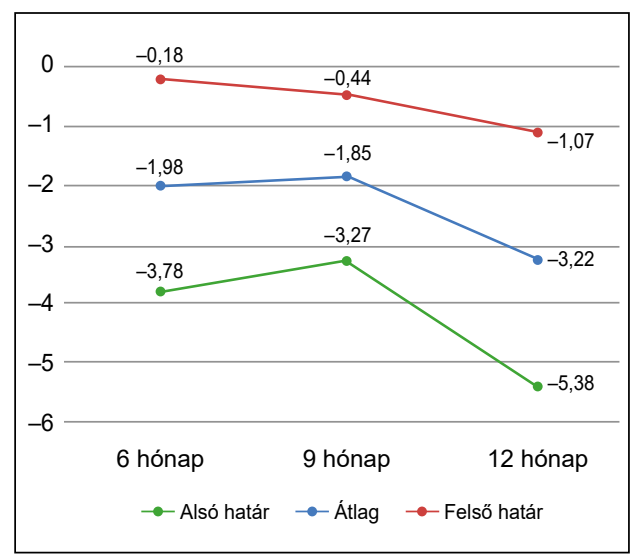

3. ábra. A HTP résztvevők $B M I$ értékeinek változása a 6. és 12. hónap közötti idöszakban

konfidencia (valószínűségi) intervallumokat kaptunk.

A vizsgálatunkban az első megjelenést követő 3. havi kontroll vizsgálatok értékeivel nem számoltunk, mivel egy életmódváltó program esetében az első három hónap még egy átállást jelent a szervezet számára, ez a „kísérletezö” időszak, itt kerül kialakításra az egyénre szabott edzés, illetve táplálkozási program. A vizsgálatunkban a 6 . és a 12 . hónap közötti időszak alatt elért változásokra fektettünk nagyobb hangsúlyt, itt néztük meg a válaszadók testösszetétel változásának folyamatát.

A testtömeg index (BMI) értékeinek változása alapján elmondható, hogy a program felénél (6 hónap) $1,98 \mathrm{~kg} / \mathrm{m}^{2}-\mathrm{t}$ csökkent átlagosan a résztvevők testtömeg indexe.

A 9. hónapnál tapasztalható egy enyhe $\left(-1,85 \mathrm{~kg} / \mathrm{m}^{2}\right)$ visszaesés, csökkenés (3. ábra), amely a viszcerális zsír értékének változásával és a testzsír \% csökkenésével hozható összefüggésbe.

A program végére (12. hónap) viszont mind a BMI, mind a viszcerális zsír vonatkozásában erős csökkenés figyelhe-

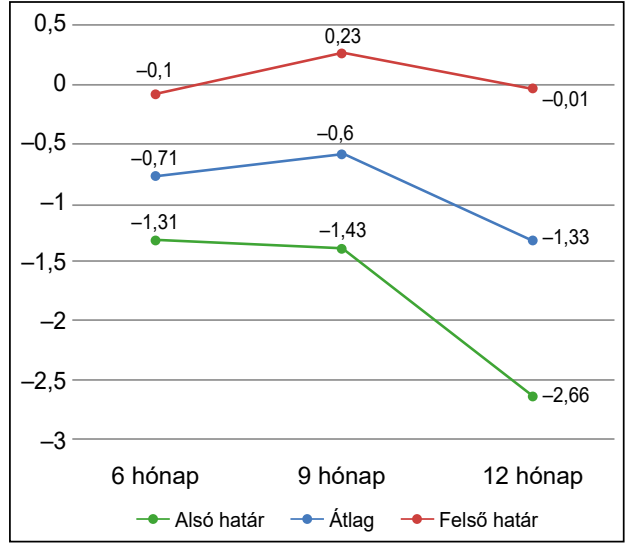

4. ábra. A HTP résztvevök viszcerális zsír értékeinek változása a 6. és a 12. hónap közötti időszakban

tő meg. Átlagosan a BMI $-3,22 \mathrm{~kg} / \mathrm{m}^{2}$, a viszcerális zsír pedig a 12 . hónapra $-1,33$ egységet csökkent (4. ábra). A testöszszetételi mutatók között a viszcerális zsír értéke az, ami a legkevésbé változott a program ideje alatt.

A HTP egyik fő célkitüzése, hogy a testtömeg csökkenést a testzsírszázalék és ne a vázizom százalék csökkenése eredményezze. Azon személyek esetében, akik a túlsúlyukból adódóan még nem tudnak megfelelő mértékben és gyakorisággal mozogni, a vázizom százalék megtartása az elsődleges feladat. $\mathrm{Az}$ ő esetükben csak a testsúlycsökkenést követően kezdődhet meg az erőnlét fokozása. A testzsír százalék értékének változása a programban eltöltött idő alatt az 5. ábrán látható. A kritikus 9. hónap esetében, azaz a 3. kontroll vizsgálat idöszakában visszaesés ugyan nem tapasztalható, de a csökkenés mértéke igen kicsi a 6. hónaphoz képest, csupán -0,37\%. A 12. hónap végére viszont átlagosan 4,04\%-ot csökkent a résztvevők testzsír százalék értéke.

A résztvevők vázizom százalék változása a program ideje alatt, 6 hónap után 


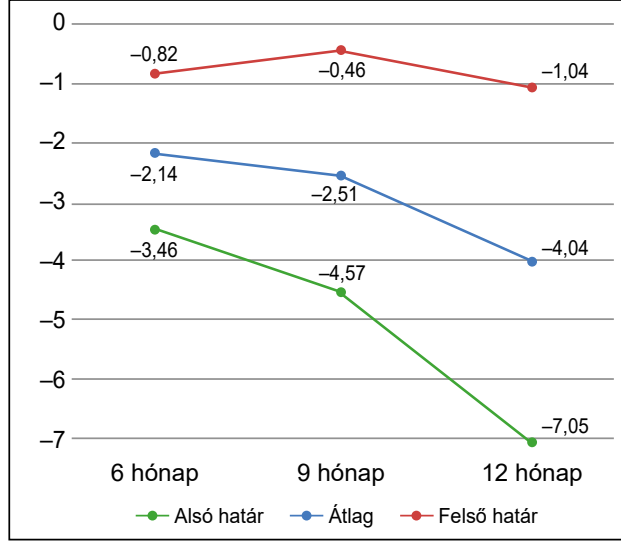

5. ábra. A HTP résztvevők testzsír (\%) értékeinek változása a 6. és 12. hónap közötti idöszakban

átlagosan 1,72\%-os növekedést mutatott (6. ábra). A kritikus 9. hónapnál ugyanakkor már visszaesés volt megfigyelhető. Átlagosan 1,28\%-os volt a csökkenés, amely a fogyás ezen szakaszában gyakran elöfordul, de aztán a 12. hónap elteltével, már ismételten növekedés figyelhető meg. Közel 2\%-os az átlagos izom százalék növekedés mértéke.

A résztvevők átlagos testtömeg változása a program ideje alatt a 7 . ábrán látható. 6 hónap után átlagosan 5,18 kg-os fogyás volt megfigyelhetö, 9 hónap után majdnem $6 \mathrm{~kg}$-ot veszítettek átlagosan a résztvevők a testsúlyukból, és a 12 . hónap elteltével pedig már majdnem $10 \mathrm{~kg}$ os volt az átlagos tömegcsökkenés.

\section{Következtetések}

A fizikai-, egészségügyi alkalmasság és a hadrafoghatóság fenntartásához nélkülözhetetlen a személyi állomány egészségtudatos életvitele. A Magyar Honvédség Egészségügyi Központja kiemelten fontosnak tartja a katonák egészségének megörzését, illetve annak fejlesztését, amely biztosításához a Honvéd Testal-

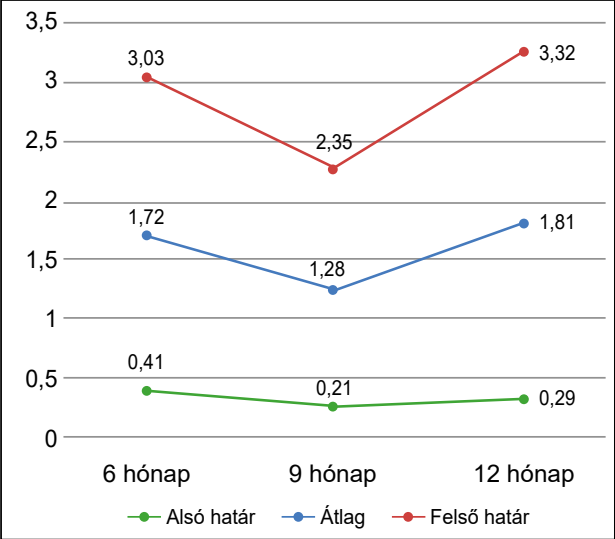

6. ábra. A HTP résztvevők vázizom (\%) értékeinek változása a 6. és 12. hónap közötti időszakban

kati Program mára elengedhetetlenné vált. A jelenleg még ajánlásként müködő HTP kiemelt helyen való kezelését jelenti továbbá az a tény is, hogy a jövőben kötelezővé válik a személyi állomány azon tagjai számára, akik a testalkati ajánlásoknak nem tesznek eleget. A programban résztvevők lemorzsoló-

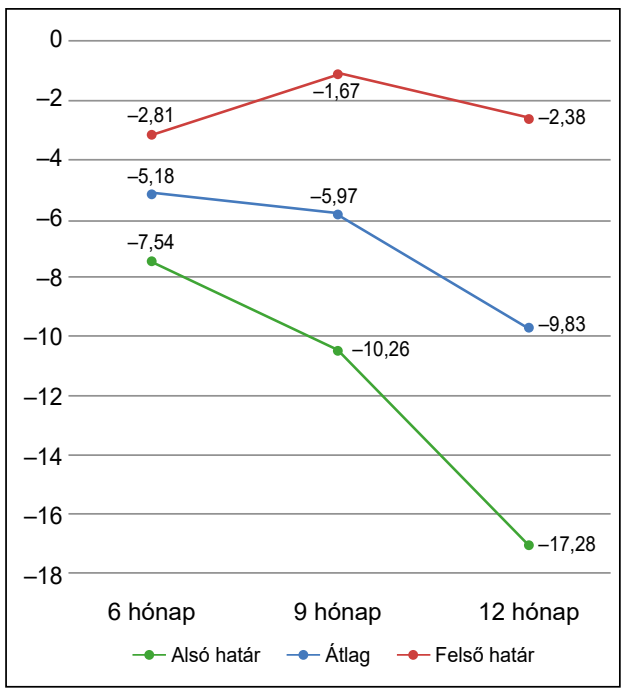

7. ábra. A HTP résztvevök testtömeg $(\mathrm{kg})$ értékeinek változása a 6. és 12. hónap közötti időszakban 
dása még igen magas, legtöbben az első kontroll vizsgálatot (3. hónap) követően adják fel. A lemorzsolódásban leginkább szerepet játszó tényezők az életmódváltás iránti elköteleződés hiánya, illetve a szolgálati elfoglaltságokból adódó időhiány. Viszont a vizsgálati eredmények azt a tényt igazolják, hogy azok, akik a személyre szabott napi, illetve heti edzésterv alapján mozogtak, és a szintén személyre szabott táplálkozási ajánlások alapján étkeztek, változtattak életmódjukon, testsúlycsökkenést, kedvező irányú testösszetétel változást értek el, valamint a funkcionális teljesítő képességük is növekedett. Így továbbra is elmondható, hogy a program szerves részét képezi a szervezeti egészségfejlesztésnek a Magyar Honvédségben és évről évre egyre sikeresebbnek mondható.

\section{Irodalom}

[1] World Health Organization: Obesity: preventing and managing the global epidemic. Report of a WHO Consultation (WHO Technical Report Series 894) Geneva, 2000

[2] Novák A., Sótér A., Rázsó Zs., Juhász Zs.: Harc az elhízás ellen: A Honvéd Testalkati Program. Honvédségi Szemle 145. évf. 2017/3. szám, 74-80. o.

[3] Szilágyi Zs., és mtsai: A mentális állóképesség - vizsgálatok bevezetésének lépései a Magyar Honvédség állományában (2006-2009). Hadtudományi Szemle, 7. évf. 1. szám, 2014, Budapest.

[4] AR 600-9. The Army Body Composition Program. 28. June 2013. http://www. wood.army.mil/sapper/document_frames/ ar600_9.pdf (Letöltés időpontja: 2016. 05. 04.)

[5] 10/2015. (VII. 30.) HM rendelet a katonai szolgálatra való egészségi, pszichikai és fizikai alkalmasságról, valamint a felülvizsgálati eljárásról. 10307. Magyar Közlöny, 111. szám.
[6] Global Physical Questionnaire http://www. who.int/ncds/surveillance/steps/resources/ GPAQ_Analysis_Guide.pdf (Letöltés időpontja: 2017. 11. 18.)

[7] Prochaska, J. O., DiClemente, C. C.: Transtheoretical therapy: Toward a more integrative model of change. Psychotherapy, Theory, Research \& Practice, 1982, 19 (3), 276.

[8] Czeglédi E.: A viselkedésváltozás transzteoretikus modelljének alkalmazási lehetőségei az elhízás kezelésében. Mentálhigiéné és Pszichoszomatika, 2012, 13(4): 411-434, DOI: 10.1556/Mental.13.2012.4.4.

[9] Czeglédi E., Urbán R.: A Háromfaktoros Evési Kérdőív (Three-Factor Eating Questionnaire Revised 21-Item) hazai adaptációja. Magyar Pszichológiai Szemle, 2010, 65(3): 463-494.

[10] Egészségjelentés. Nemzeti Egészségfejlesztési Intézet, Budapest, 2016, 45-46.

[11] Stauder A., Konkolÿ Thege B.: Az Észlelt Stressz Kérdőív (PSS) magyar verziójának jellemzői. Mentálhigiéné és Pszichoszomatika, 2006, 7: 203-216.

[12] Oláh A.: Útmutató a Pszichológiai Immunkompetencia Kérdöív (PIK) használatához. ELTE, Budapest, 1999.

[13] Exercise Motivation Inventory-2 http:// pages.bangor.ac.uk/ pes004/exercise_ motivation/emi/emi-2.htm

\section{Lt.Col. Zs. Juhász PhD, 2ndLt. Zsófia Rázsó}

\section{Experiences of the Hungarian Defence Forces Body Composition Program}

The leadership of the Hungarian Defense Forces in the Zrínyi 2026 Military Force Development Program pays special attention to the development and maintenance of a healthy lifestyle for soldiers. The main goal of the Hungarian Defence Forces Body Composition Program (hereinafter: Prog- 
ram) - which has been running since 2015 - to support the 12 month lifestyle change of people with excess weight. The Program based on the Army Body Composition Program (AR 600-9, 2013) which is running in the US Army, this professional activity is materialized within the framework of workplace the health promotion.

There are very good results in terms of lifestyle changes for those who have completed the 12 month program. After one year, the BMI decreased by an average of $5 \mathrm{~kg} / \mathrm{m}^{2}$, the average body weight change was $-16 \mathrm{~kg}$, and the average decrease in body fat percentage was $6 \%$. After one year, the visceral fat decreases by an average of 2 units. In terms of motivational structure, the most motivating factors are positive health (ill-health avoidance), weight management, revitalisation, and strengthendurance. The results confirm that supporting the lifestyle change which is the part of the force health protection, contributes to maintaining the combat capability and long-term working ability of the military members.

Key-words: health, HDF Body Composition Program, lifestyle change, Hungarian Defence Forces

Dr. Juhász Zsolt alez., PhD 1134 Budapest, Róbert Károly krt. 44. 